\title{
Insect damage to cones and other mortality factors limiting natural regeneration potential of Swiss stone pine (Pinus cembra $L$ ) in the northern French Alps
}

\author{
L Dormont 1, 2, A Roques 1, L Trosset ${ }^{2}$ \\ 1 Station de zoologie forestière, CRF-Orléans, INRA, Ardon, 45160 Olivet; \\ 2 Laboratoire dynamique des écosystèmes d'altitude, CISM, campus scientifique, \\ université de Savoie, 73376 Le Bourget-du-Lac cedex, France
}

(Received 21 November 1994; accepted 13 March 1995)

\begin{abstract}
Summary - A seed cone population of Swiss stone pine was surveyed from flower bud burst to cone maturation during 1992-1993. The potential seed crop was estimated to decrease by $84 \%$ of the initial value. Mortality was mainly caused by abiotic factors during the first year of cone development while cone insects caused most damage to second-year cones. The cone entomofauna only included three phytophagous species, and largely differed from the fauna observed in cones of other Alpine conifers.
\end{abstract}

Pinus cembra / regeneration / cone insect / seed loss

Résumé - Les dégats d'insectes des cônes et autres facteurs de mortalité limitant les potentialités de régénération naturelle du pin cembro dans les Alpes françaises du Nord. Un suivi démographique de cônes de pin cembro sur un cycle reproductif complet a été réalisé en 1992 et 1993. Au total, $84 \%$ de la production potentielle de graines a été détruite. La majorité des pertes a été causée par des facteurs abiotiques la première année, et par des insectes pour les cônes de deuxième année. L'entomofaune ne comprend que trois espèces phytophages et diffère largement de celle observée dans les autres essences des conifères alpins.

Pinus cembra / régénération / insecte des cônes / perte en graines 


\section{INTRODUCTION}

Insects exploiting seed cones are known to limit the potential of natural regeneration in high altitude conifer forests. In larch, such insects may currently reduce the annual number of seeds by 50 to $80 \%$ in the French Alps, and even by $100 \%$ in mountains of northeastern China (Roques, 1993). However, insects exploiting seed cones of Swiss stone pine (Pinus cembra $L$ ) have received little attention (Coslop and Masutti, 1978; Roques, 1983). Moreover, the decrease in seed yield that results from insect damage during the seed predispersal phase has never been quantified. Our study thus aimed to assess the species composition and biology of the entomofauna feeding on seed cones of $P$ cembra, and then to measure the respective impact of insects and other mortality factors on the potential of natural regeneration of stone pine forests. Insect damage has usually been measured using periodic dissections of cones collected at successive dates. By contrast, we intented to survey the same reproductive structures over their whole development, from flower bud burst to seed maturation.

\section{MATERIALS AND METHODS}

The survey was carried out in the forest of Tuéda, near Méribel-Les-Allues $\left(45^{\circ} 21 ' \mathrm{~N}, 6^{\circ} 38^{\prime} \mathrm{E}\right)$, in the northern French Alps. The Tuéda forest ranges from 1700 to $2000 \mathrm{~m}$, and is the largest pure stand of $P$ cembra in the region although mixed with spruce at low altitude. In June 1992, 20 conebearing trees were randomly selected throughout the forest. Six branches bearing both conelets and second-year cones were selected per tree and tagged. The position of the conelets and cones was mapped, and the branches were then surveyed according to the methods developed by Ebel and Yates (1974) and Rauf et al (1985). $A$ total of 500 conelets were surveyed over a complete reproductive cycle, from June 1992 to September 1993, while 480 second-year cones (ie, initiated in 1991) were surveyed from June to September 1992. In September 1992 and 1993, the surviving second-year cones were harvested for seed extraction. All seed lots were Xrayed to measure the respective number of filled, insect-damaged and aborted seeds. In 1992 and 1993,10 cone-bearing trees were additionally sampled nearby the trees considered earlier. A monthly collection of 5 cones per tree was performed on these trees from June to September. The sampled cones were immediately dissected in order to identify the damaging larvae and to assess the type and importance of damage (Roques, 1983). Insects were either preserved in $70 \%$ alcohol or raised to the adult stage.

\section{RESULTS}

\section{Cone entomofauna of Swiss stone pine}

Three phytophagous species were observed to attack the seed cones of Swiss stone pine. The weevil Polydrusus atomarius Olivier (Coleoptera: Curculionidae) had never been recorded to attack conelets of $P$ cembra until our observations. Adults fed on external surfaces and attack usually resulted in conelet abortion. Larvae of the midge Cecidomyia pini De Geer (Diptera: Cecidomyiidae) developed in tissues and resin of first-year cones. Midge attack resulted in a typical twisted shape of the subsequent second-year cones in which most of the seeds aborted. Larvae of the cone pyralid, Dioryctria abietella Denis and Schiffermüller (Lepidoptera: Pyralidae), entered the second-year cones and fed on cone tissues (scales, cone axis). A few were found preying seeds. The three species were already known to attack twigs, shoots and other cone species (Roques, 1983).

\section{Factors of mortality acting during seed cone development (table I)}

During the first year of development, $66 \%$ of the conelets disappeared, mainly because 
Table I. Life table for the $1992-1993$ cone crop of Swiss stone pine from bud burst to seed maturation, forest of Tuéda, northern French Alps.

\begin{tabular}{|c|c|c|c|c|c|c|c|}
\hline Development stage & Date & $\begin{array}{c}\text { No of } \\
\text { survivors }\end{array}$ & $\begin{array}{c}\mathrm{No} / \\
\text { branch }\end{array}$ & $\begin{array}{l}\text { Mortality } \\
\text { factor }\end{array}$ & $\begin{array}{c}\text { Death } \\
\text { (no) }\end{array}$ & $\begin{array}{l}\text { Mortality } \\
\text { quotient }\end{array}$ & $\begin{array}{l}\text { Survival } \\
\text { rate }\end{array}$ \\
\hline Flower bud burst & 16 VI 92 & 500 & 4.16 & & & & \\
\hline 0.5-month conelet & 30 VI 92 & 453 & 3.77 & Development lacking & 47 & 9.4 & 90.6 \\
\hline 1-month conelet & 14 VII 92 & 444 & 3.70 & Polydrusus & 9 & 1.98 & 98.1 \\
\hline 1.5-month conelet & 30 VII 92 & 343 & 2.85 & $\begin{array}{l}\text { Abortion } \\
\text { Polydrusus }\end{array}$ & $\begin{array}{l}79 \\
22 \\
101\end{array}$ & $\begin{array}{l}17.7 \\
4.9 \\
22.8\end{array}$ & 77.2 \\
\hline 2-month conelet & 16 VIII 92 & 280 & 2.33 & $\begin{array}{l}\text { Disappeared } \\
\text { Abortion } \\
\text { Polydrusus }\end{array}$ & $\begin{array}{c}42 \\
1 \\
20 \\
63\end{array}$ & $\begin{array}{c}12.2 \\
0.2 \\
5.8 \\
18.4\end{array}$ & 81.6 \\
\hline 3-month conelet & $141 \times 92$ & 227 & 1.89 & Disappeared & 53 & 18.9 & 81.1 \\
\hline 11-month cone & $25 \vee 93$ & 167 & 1.39 & $\begin{array}{l}\text { Disappeared } \\
\text { Frost }\end{array}$ & $\begin{array}{l}20 \\
40 \\
60\end{array}$ & $\begin{array}{c}8.8 \\
17.6 \\
26.4\end{array}$ & 73.6 \\
\hline 12-month cone & $20 \mathrm{VI} 93$ & 167 & 1.39 & & 0 & 0 & 100 \\
\hline 15-month cone & $81 \times 93$ & 70 & 0.58 & $\begin{array}{l}\text { Cecidomyia } \\
\text { Dioryctria }\end{array}$ & $\begin{array}{r}53 \\
44 \\
97\end{array}$ & $\begin{array}{l}31.7 \\
26.3 \\
58.0\end{array}$ & 41.9 \\
\hline
\end{tabular}

of abiotic factors ( $85 \%$ of the losses), but $11.8 \%$ of the conelets aborted following the attack of $P$ atomarius. Conelet attack by the midge $C$ pini could only be quantified during the second year of development because no damage was visible from outside during the early stages of cone development. Mortality of the second-year cones was predominantly caused by insects, involving larvae of $C$ pini and $D$ abietella that attacked 32 and $26 \%$ of the cones, respectively.
Relative importance of mortality factors in decreasing the potential seed crop (fig 1)

A sound cone yielded an average of $41 \pm$ 15 seeds (max: 78 , min: $14 ; n=50$ ). The potential seed crop expected to result from the 500 conelets tagged in June 1992 was therefore extrapolated to 20500 seeds, on the average. $X$ rays showed that aborted and undeveloped seeds averaged $8.9 \pm$ $6.1 \%$ in sound mature cones $(n=50)$ but 


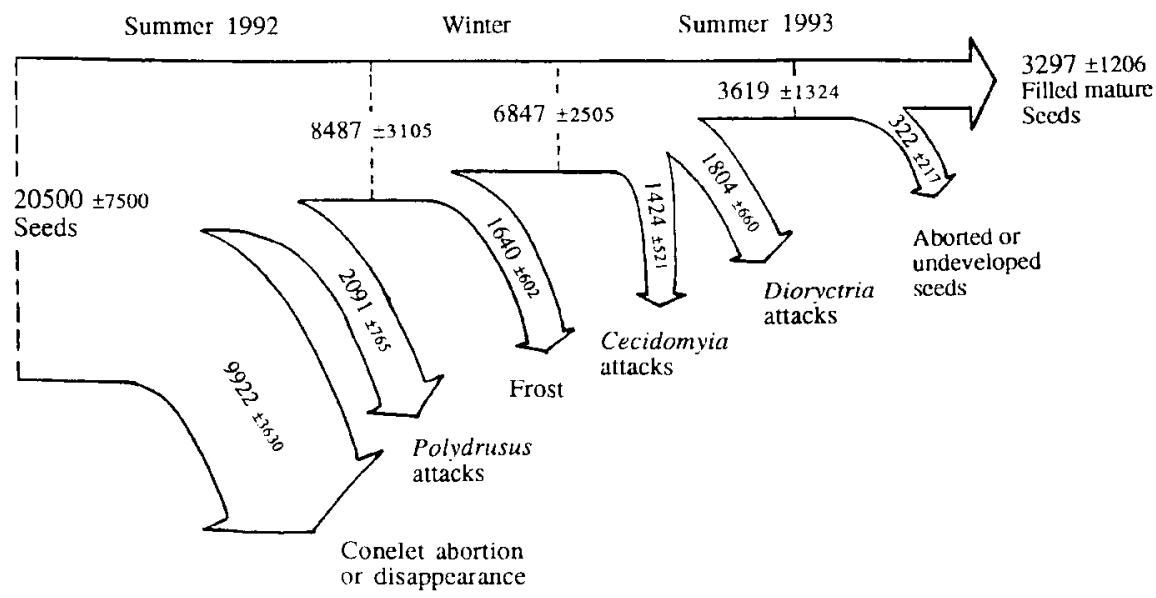

Fig 1. Mortality factors of Pinus cembra seed cones and estimation of their seasonal impact during a reproductive cycle 1992-1993, forest of Tuéda, northern French Alps (average number of seeds $\pm \mathrm{SD}$ ).

$65 \%$ of the potential seed content aborted when a first-year cone was attacked by $C$ pini. Infestation of second-year cones by Dioryctria larvae also resulted in a loss of the entire seed content because such cones with visible frass were always forsaken by the nutcracker, and seeds were thus unable to escape the serotinous cones and be dispersed. Finally, the potential seed crop was estimated to decrease by $84 \%$ of the initial value, insect damage accounting for $31 \%$ of the decrease.

\section{DISCUSSION}

The seed cone entomofauna of $P$ cembra appeared markedly different from that observed in cones of other Alpine conifer species (Roques, 1983, 1993). Cones of larch, spruce, fir and mountain pine generally host a larger number of species (nine to 17 according to tree species) and show greater insect damage (Roques, 1993). Moreover, most cone insects are host-specific and highly specialized in exploiting cone resource, a given number of species being fully adapted to seed exploitation (ie, spermatophages) (Turgeon et al, 1994). In contrast, the exploitation of the cone niche appeared incomplete in Swiss stone pine. No spermatophagous insect was noted, and none of the 3 insect species was apparently specialist of $P$ cembra cones. Additional cone collections performed all over the Alps during 1994 confirmed these preliminary results (Dormont and Roques, unpublished observations). The cone entomofauna was similarly limited in two related pine species of the cembrae subsection, $P$ pumila Regel (Khomentovsky and Efremova, 1991) and $P$ sibirica Du Tour (Florov, 1951). In both cases, the fauna consisted of two or three insect species that are taxonomically and 
ecologically close to those attacking cones of $P$ cembra. These similarities lead to assume that specific physical and/or chemical barrier, as well as biotic barrier - seed predation by nutcracker - may limit insect colonization of stone pine cones (Dormont, 1993).

Similar phenological relationships between seed cone development and action of mortality factors, especially insect attack, have been observed in Pinus spp other than stone pines (Ebel and Yates, 1974; Roques, 1977; Mattson, 1978; Rauf et al, 1985). However, stone pines differ because of the additional harvest of the surviving secondyear cones by the spotted nutcracker, Nucifraga caryocatactes $\mathrm{L}$. The nutcracker-stone pine relationships are considered both coevolved and mutualistic, the bird action allowing wingless seeds to escape from indehiscent cones, and to disseminate and colonize new areas (Mattes, 1982; Crocq, 1990; Khomentovsky and Efremova, 1991). The nutcracker harvests and hides pine seeds by the end of summer, and stored seeds not used during the following winter may thus germinate in sites very suitable for germination (Mattes, 1982; Crocq, 1990). On the other hand, Crocq (1990) reported that all of the hidden seeds were recovered afterwards by the spotted nutcracker during poor crop years. The combined action of bird and insects could thus hinder pine recruitment in most years because good cone crops usually occur only every 5-6 years in $P$ cembra stands (Contini and Lavarelo, 1982; Mattes, 1982). Moreover, additional seed predators such as squirrels, small rodents and other seed-eating birds were not taken into consideration (Smith and Balda, 1979). Difference in insect damage to seeds between larch and Swiss stone pine may also influence the development of forests where the two species are mixed. The higher damage to larch seeds could be speculated to result in the faster development of Swiss stone pine that is usually observed in mixed stands (Piussi, 1994). However, insect impact on both species was only compared at the cone or tree level (Roques, 1993). Further studies will have to supply accurate measures of the respective number of filled seeds dispersed per tree species and per surface unit.

\section{ACKNOWLEDGMENTS}

We thank $E$ De Guillebon, National Park of Vanoise, A Collas, National Forestry Office of Savoie, D Rougon, University of Orléans, JP Raimbault, INRA, Orléans, and the city of MéribelLes-Allues for support and technical assistance. This work was partly supported by a grant from the French Ministry of Environment (EGPN committee): "Dynamique et biodiversité des structures des peuplements de pin cembro".

\section{REFERENCES}

Contini L, Lavarelo $Y$ (1982) Le pin cembro (Pinus cembra $L$ ). Répartition, écologie, sylviculture et production. INRA, Versailles, France, $198 \mathrm{p}$

Coslop D, Masutti L (1978) Animali e seme di Pinus cembra $L$ al Passo di Lavazè (Dolomiti). Frust Entomol (new ser) 1, 99-122

Crocq C (1990) Le casse-noix moucheté (Nucifraga caryocatactes $L$ ). R Lechevalier, $328 \mathrm{p}$

Dormont L (1993) Insectes ravageurs de cônes et régénération des forêts d'altitude : le cas du pin cembro (Pinus cembra L). Mémoire de DEA, univ Paris$\mathrm{XI}$, France, $26 \mathrm{p}$

Ebel BH, Yates $\mathrm{HO}(1974)$ Insect-caused damage and mortality to conelets, cones and seed of shortleaf pine. J Econ Entomol 67, 222-226

Florov DN (1951) Pests of Pinus sibirica Mayr. I. Cone and seed pests of $P$ sibirica. Obl gosudarstv. Izdate|'stvo, Irkoutsk, 8-28 [In Russian]

Khomentovsky A, Efremova LS (1991) Seed production and cone-feeding insects of Pinus pumila on the Kamtchatka peninsula: aspects of coexistence. In: Forest insect guilds: pattern of interaction with hosttrees (YN Baranchikov, WJ Mattson, FP Hain, TL Pain, eds), US For Serv Tech Rep NE-153, 316-320

Mattes $\mathrm{H}$ (1982) Die Lebengemeinschaft von Tannenhäher und Arve. Swiss Federal Institute of Forestry Research, Berichte, Switzerland, $n^{\circ} 241,73 p$

Mattson WJ (1978) The role of insects in the dynamics of cone production in red pine. Oecologia $33,327-349$ 
Piussi P (1994) Mixed Pinus cembra stands on the southern slope of the Eastern Alps. In: Proceedings International Workshop on Subalpine Stone Pine and Their Environment: the Status of Our Knowledge (WC Schmidt, FK Holtmeier, eds), USDA For Serv, Bozeman, MT, USA, 261-268

Rauf A, Benjarnin DM, Cecich RA (1985) Insects affecting seed production of Jack pine, and life tables of conelet and cone mortality in Wisconsin. For Sci31, 271-281

Roques A (1977) Étude du complexe entomologique lié aux cônes de pin sylvestre en forêt de Fontainebleau. Bull Ecol 8, 415-434

Roques A (1983) Les insectes ravageurs des cônes et graines de conifères en France. INRA, Versailles, France, $135 \mathrm{p}$
Roques A (1993) Impact of insects on natural regeneration of high altitude alpine forests. In: Ecologia delle foreste d'alta quota, XXX Corso di Cultura in Ecologia (T Andofillo, C Urbinati, eds), Padova, Italy, 71-94

Roques A, Raimbault JP, Delplanque A (1984) Les diptères Anthomyiidae du genre Lasiomma Stein ravageurs des cônes et graines de Mélèze (Larix decidua Mill) en France. II. Cycles biologiques et dégâts. J Appl Entomol 98, 350-367

Smith CC, Balda RP (1979) Competition among insects, birds and mammals for conifer seeds. Am Zool 19, 1065-1083

Turgeon JJ, Roques A, De Groot P (1994) Insect fauna of coniferous seed cones. Ann Rev Entomol 39, 179212 